\title{
Reproductive deficiency in bulls from synthetic breeds according to the type of crossbreed and the morphology of the $\mathrm{Y}$ chromosome
}

\author{
Marilise M. Horn ${ }^{1}$, José C.F. Moraes ${ }^{2}$, Carlos M. Jaume ${ }^{2}$, Maria I.A. Edelweiss ${ }^{3}$ and Adriano Rosado ${ }^{4}$ \\ ${ }^{1}$ Universidade Federal do Rio Grande do Sul, Faculdade de Veterinária, Porto Alegre, RS, Brazil. \\ ${ }^{2}$ Embrapa Pecuária Sul, Bagé, Rio Grande do Sul, Brazil. \\ ${ }^{3}$ Universidade Federal do Rio Grande do Sul, Faculdade de Medicina, Departamento de Patologia, \\ Porto Alegre, RS, Brazil. \\ ${ }^{4}$ Veterinário, Dom Pedrito, Rio Grande do Sul, RS, Brazil.
}

\begin{abstract}
We used 550 Braford and 214 Brangus-lbagé bulls to study the association between $Y$ chromosome morphology and the evaluation of breeding-soundness, karyotyping and breeding records were used to assess $Y$ chromosome morphology. In general, no direct association was detected between the individual type of $Y$ chromosome and reproductive fitness as previously estimated through breeding soundness examination. The type of breeding strategy used to form the synthetic breeds was also analyzed. The Braford breed is about 3/8 Zebu (Bos taurus indicus) and 5/8 Hereford (Bos taurus taurus) but when the breeding strategy used 1/4 Zebu animals to produce Braford bulls which were 3/8 Zebu a greater percentage of the bulls had to be culled due to reproductive problems. Our study shows that certain interactions between genotypes can be detrimental to the reproductive efficiency of $3 / 8$ Zebu animals and that breeding strategies avoiding or favoring certain genotypes can be used to reduce the percentage of bulls from synthetic breeds that are culled due to problems with semen quality.
\end{abstract}

Key words: bulls, semen quality, Y chromosome, synthetic breeds of cattle.

Received: March 8, 2004; Accepted: August 18, 2004.

\section{Introduction}

In spite of their common ancestral base Asiatic Zebu cattle (Bos taurus indicus) and European taurine cattle (Bos taurus taurus) exhibit several morphological and physiological differences (Wurster and Benirschke, 1968). The karyotypes of these two bovine sub-species are similar, consisting of 58 acrocentric autosomes and two sexual chromosomes, a submetacentric $\mathrm{X}$ chromosome and a $\mathrm{Y}$ chromosome whose morphology varies depending on the sub-species (Kieffer and Cartwright, 1968); the Y-chromosome found in B.t. taurus being submetacentric while that in B.t. indicus is acrocentric. These two types of $\mathrm{Y}$ chromosome also occur in bulls of the synthetic Brangus-Ibagé breed (Pinheiro et al., 1979) and in 'Pé Duro' bulls (Britto and Mello, 1999) (an ancient European breed raised in Brazil) indicating miscegenation. According to Kieffer and Cartwright (1968) the difference in the Y chromosome between the taurus and indicus sub-species is a consequence of pericentric inversion and this was later con-

Send correspondence to José Carlos Ferrugem Moraes. Embrapa Pecuária Sul, Caixa Postal 242, 96401-970 Bagé, RS, Brazil. E-mail: ferrugem@cppsul.embrapa.br. firmed by Pinheiro et al. (1980) based on G and C-band patterns. Halnan (1989) reviewed Y chromosome variants and fertility in more than 30 breeds and suggested that the $Y$ chromosome could be used as a racial marker and to produce a genetic model capable of explaining the low reproductive rate of bulls derived from Zebu crosses in Australia. The lower fertility in Zebu crosses with European cattle could be due to small deletions or position changes between the synapse region of the $\mathrm{X}$ and $\mathrm{Y}$ chromosomes, or to alterations in genes participating in the regulation of reproduction.

It is known that the Y-chromosome possesses genes related to spermatogenesis (Foresta et al., 1997), one example being the Sxra region of the rat Y-chromosome which contains genes related to the determination of the male gender and which participate during the last stages of spermatogenesis (Cooke, 1999). There is evidence from various species of irregularities occurring during the meiosis of $\mathrm{F} 1$ products and backcrosses, with fertility problems having been reported in the heterogametic sex in bovines (Basrur and Moon, 1967), Drosophila (Lamnissou et al., 1996; Joly et al., 1997; Snook, 1998) and rodents (Hale et al. 1993; Kaku et al., 1995), the example in rodents being 
particularly interesting because of the occurrence of fertile and infertile males depending on the type of backcross from which they arose (Hale et al. 1993).

A greater percentage of bulls with indicators of reduced potential fertility have been found in synthetic breeds in comparison with their parental pure breeds (Chenoweth et al., 1996; Chacón et al., 1999). In a population of 751 bulls raised in southern Brazil the culling rate due to alterations in semen quality was $47 \%$ for Braford bulls but only $18 \%$ for Hereford bulls raised under the same conditions (Moraes et al., 1998). According to various authors between 80 and $90 \%$ of purebred animals have no reproductive problems (Johnson et al., 1995; Bruner et al., 1995; Gottschall and Mattos, 1997; Ribeiro Filho et al., 1997; Kennedy et al., 2002) but in their study of 48 crossbred bulls Rao and Rao (1991) found that only $47 \%$ could be considered reproductively sound.

The breeding strategies used to obtain synthetic breeds offers an ideal model to study a possible association between Y chromosome morphology and fertility because both types of Y chromosome coexist in the same racial group. The hypothesis which we tested was that there would be a greater incidence of alterations in the spermatogenesis of crossbred males due to gene modifications resulting from the rearrangement caused by variation in $\mathrm{Y}$ chromosome morphology which could lead to alterations in enzymes or other proteins. The objective of our study was to identify the relationships between $\mathrm{Y}$ chromosome morphological type, crossbreeding type and reproductive fitness of bulls from synthetic breeds of cattle.

\section{Material and Methods}

We prepared karyotypes from lymphocyte cultures of 76 Braford and 21 Brangus bulls and identified the Y chromosome morphology for each bull. In addition we used genealogical analysis to investigated the type of $\mathrm{Y}$ chromosome present in 474 Braford and 193 BrangusIbagé bulls with known paternal genotypes.

The bulls used in this study had previously been evaluated for reproductive soundness according to the specifications of the Brazilian Society for Animal Reproduction (Government edict n. 26 from 05/09/1996, www. agricultura.gov.br) which states that to be considered as being fit for breeding a bull must present no more than $30 \%$ of abnormal sperm and $>50 \%$ sperm-motility with a vigor of $>3$ on a $0-5$ scale, bulls not conforming to these criteria were considered reproductively unfit for our study. The bulls were raised on two private properties and at South Embrapa Cattle \& Sheep (Centre Embrapa, the Brazilian Agricultural Research Corporation) near the town of Bagé, Rio Grande do Sul state, southern Brazil. In summer the bulls grazed on native pastures, composed principally of Paspalun sp. and Axonopus sp., and in winter on cultivated pastures consisting of
Trifolium repens, Lotus corniculatus and Lolium multiflorum, when the bulls were two years old at which point they were subjected to pre-sale breeding soundness evaluation.

For the 97 karyotyped bulls, the area around the tail-vein was cleaned and disinfected with $70 \%(\mathrm{v} / \mathrm{v})$ alcohol and blood samples collected from the tail-vein using heparinized syringes, the samples being kept at $5-10{ }^{\circ} \mathrm{C}$ and transported to the laboratory within $24 \mathrm{~h}$. Lymphocyte cultures were produced for each bull by adding four drops of blood to $10 \mathrm{~mL}$ of karyotyping medium containing phytohemagglutinin (Cultilab) and incubating the cultures for $72 \mathrm{~h}$ with gentle shaking for a few seconds every $12 \mathrm{~h}, 50 \mu \mathrm{L}$ of a $0.025 \%$ (w/v) colchicine solution (Sigma) being added after $70 \mathrm{~h}$ incubation. After $72 \mathrm{~h}$ incubation cultures were centrifuged at 1000 revs $\mathrm{min}^{-1}$ for $5 \mathrm{~min}$ and the supernatants separated, $4 \mathrm{~mL}$ of 0.075 molar potassium chloride was added to the pelleted cells to produce hypotonicity and the mixture allowed to stand for $15 \mathrm{~min}$ before adding $4 \mathrm{~mL}$ of Carnoy's fluid (3:1 (v/v) methanol/acetic acid) fixative and allowing the cells to fix for $24 \mathrm{~h}$ after which they were centrifuged and washed three times with the same volume of Carnoy fixative. Slides were made by placing a few drops of the fixed material onto cold microscope slides which were then flamed and stained with Giemsa and examined by clear-field microscopy at 1000x magnification, Y chromosome morphology being determined by examining five metaphases from each bull.

We also used genealogical data to investigated 667 bulls (474 Braford and 193 Brangus-Ibagé) with known paternal genotypes and compare the results with those from the karyotyped bulls. Genealogical data covering three years (1998-2000) were used for the Braford bulls and eight years (1992-2000) for the Brangus-Ibagé bulls. Table 1 presents the different matings used to obtain the animals with different degrees of crossbreeding established in the formation of the synthetic breeds. Both male and female 1/4 Hereford or Aberdeen Angus x 3/4 Nellore were obtained by mating Nellore bulls with $1 / 2$ blood females but bulls with this genotype combination were not evaluated with respect their breeding soundness and data for this mating type is not included in Table 1.

The analysis of the association between the reproductive condition (fit or unfit) of the bulls and the morphological type of the $\mathrm{Y}$ chromosome (acrocentric or submetacentric) or the different matings was carried out by using the chi-square $\left(\chi^{2}\right)$ likelihood-ratio method using the PEPI package, Statistical Programs for Epidemiologists, version 3.0 (www.usd-inc.com/pepi. html) with the Yates correction being applied whenever the comparisons involved less than 100 animals. 
Table 1 - Matings used to obtain Braford (5/8 Hereford x 3/8 Nellore) and Brangus-Ibagé (5/8 Aberdeen Angus x 3/8 Nellore) synthetic bulls.

\begin{tabular}{|c|c|c|}
\hline Type of mating & Offspring & Parents \\
\hline 1 & $1 / 2$ & $\begin{array}{l}\text { Male Nellore x Female Hereford or } \\
\text { Aberdeen Angus }\end{array}$ \\
\hline 2 & $1 / 4$ & $\begin{array}{l}\text { Male Hereford or Aberdeen Angus } x \\
\text { Female } 1 / 2 \text { Nellore }\end{array}$ \\
\hline 3 & $1 / 4$ & $\begin{array}{l}\text { Male } 1 / 2 \times \text { Female Hereford or } \\
\text { Aberdeen Angus }\end{array}$ \\
\hline 4 & $3 / 8$ & $\begin{array}{l}\text { Male Hereford or Aberdeen Angus x } \\
\text { Female } 3 / 4 \text { Nellore }\end{array}$ \\
\hline 5 & $3 / 8$ & $\begin{array}{l}\text { Male } 3 / 4 \text { Nellore x Female Hereford } \\
\text { or Aberdeen Angus }\end{array}$ \\
\hline 6 & $3 / 8$ & Male $1 / 2 \times$ Female $1 / 4$ Nellore \\
\hline 7 & $3 / 8$ & $\begin{array}{l}\text { Male } 1 / 4 \text { Nellore x Female } 1 / 2 \\
\text { Nellore }\end{array}$ \\
\hline 8 & $3 / 8$ & $3 / 8 \times 3 / 8$ Nellore \\
\hline
\end{tabular}

\section{Results}

Of the sample of 97 bulls (76 Braford and 21 Brangus-Ibagé) used in the karyotype study, 55 were diagnosed as fit and 42 considered unfit for reproduction, Table 2 showing the frequencies of each type of $\mathrm{Y}$ chromosome as evaluated using karyotype analysis.

For the Braford group the percentage of fit and unfit bulls with the two Y chromosome types were similar $\left(\chi^{2}=1.053 ; \mathrm{DF}=1 ; \mathrm{p}=0.305\right)$. In the smaller of Brangus-Ibagé sample although there was an apparent excess of fit bulls with an acrocentric Y chromosome there was also no significant difference between fit and unfit bulls $\left(\chi^{2}=0.032 ; \mathrm{DF}=1 ; \mathrm{p}=0.859\right)$. In both breeds, no association was detected between $\mathrm{Y}$ chromosome morphology and reproductive fitness $\left(\chi^{2}=0.681 ; \mathrm{DF}=1 ; \mathrm{p}=0.409\right)$. Excluding $\mathrm{Y}$ chromosome morphology from the analysis, there was a higher frequency of fit Brangus-Ibagé bulls than Braford bulls $\left(\chi^{2}=5.222 ; \mathrm{DF}=1 ; \mathrm{p}=0.022\right)$.

Chromosome analysis revealed that genealogical data was imprecise only for the production of the $1 / 4$ offspring (mating types 2 and 3), necessary for obtaining the 5/8 European and $3 / 8$ Zebu crossbreds (Table 1 ), because a multiple sire mating system was used to obtain this genotype.

Table 3 shows the frequency of reproductively fit and unfit Braford bulls according to their genealogically determined Y chromosome morphology. In 471 Braford bulls (excluding bulls from mating type 4) the frequency of fit and unfit bulls was similar between mating types $\left(\chi^{2}=9.949 ; \mathrm{DF}=6 ; \mathrm{p}=0.127\right)$. For bulls carrying an acrocentric Y chromosome there was a significant deviation between mating types $\left(\chi^{2}=9.735\right.$; $\left.\mathrm{DF}=4 ; \mathrm{p}=0.045\right)$, unfit bulls being more prevalent in mating types 1 and 6 and less prevalent in types 5 and 8 . In contrast, this interaction was not significant for bulls carrying a submetacentric $\mathrm{Y}$ chromosome $\left(\chi^{2}=1.773 ; \mathrm{DF}=3 ; \mathrm{p}=0.621\right)$. In the genea-

Table 2 - Cytogenetically determined frequency of the different types of Y chromosomes in Braford and Brangus-Ibagé bulls which had been classified by breeding soundness evaluation.

\begin{tabular}{|c|c|c|c|c|c|c|c|}
\hline \multirow[b]{3}{*}{ Breed } & \multicolumn{6}{|c|}{ Y chromosome morphology } & \multirow[b]{3}{*}{$\begin{array}{c}\text { Total } \\
\text { unfit }+ \text { fit }\end{array}$} \\
\hline & \multicolumn{3}{|c|}{ Unfit bulls } & \multicolumn{3}{|c|}{ Fit bulls } & \\
\hline & $\begin{array}{l}\text { Acrocentric } \\
\text { number }(\%)\end{array}$ & $\begin{array}{l}\text { Submetacentric } \\
\text { number }(\%)\end{array}$ & Total unfit & $\begin{array}{l}\text { Acrocentric } \\
\text { number }(\%)\end{array}$ & $\begin{array}{l}\text { Submetacentric } \\
\text { number }(\%)\end{array}$ & Total fit & \\
\hline Braford & $25(33)$ & $13(17)$ & 38 & $30(39)$ & $8(11)$ & 38 & 76 \\
\hline Brangus-Ibagé & $3(14)$ & $1(5)$ & 4 & $12(57)$ & $5(24)$ & 17 & 21 \\
\hline Total & $28(29)$ & $14(14)$ & 42 & $42(43)$ & $13(14)$ & 55 & 97 \\
\hline
\end{tabular}

Table 3 - Genealogically determined frequency of the different Y chromosome morphological types found in reproductively fit and unfit Braford bulls.

\begin{tabular}{|c|c|c|c|c|c|c|c|}
\hline \multirow[b]{3}{*}{ Mating type } & \multicolumn{6}{|c|}{ Y chromosome morphology } & \multirow[b]{3}{*}{$\begin{array}{c}\text { Total } \\
\text { unfit }+ \text { fit }\end{array}$} \\
\hline & \multicolumn{3}{|c|}{ Unfit bulls } & \multicolumn{3}{|c|}{ Fit bulls } & \\
\hline & $\begin{array}{l}\text { Acrocentric } \\
\text { number }(\%)\end{array}$ & $\begin{array}{l}\text { Submetacentric } \\
\text { number }(\%)\end{array}$ & Total unfit & $\begin{array}{l}\text { Acrocentric } \\
\text { number }(\%)\end{array}$ & $\begin{array}{l}\text { Submetacentric } \\
\text { number }(\%)\end{array}$ & Total fit & \\
\hline 1 & $19(38)$ & - & 19 & $31(62)$ & - & 31 & 50 \\
\hline 2 & - & $33(33)$ & 33 & - & $66(66)$ & 66 & 99 \\
\hline 3 & $12(23)$ & - & 12 & $40(77)$ & - & 40 & 52 \\
\hline 4 & - & $2(67)$ & 2 & - & $1(33)$ & 1 & 3 \\
\hline 5 & $4(15)$ & - & 4 & $23(85)$ & - & 23 & 27 \\
\hline 6 & $27(42)$ & - & 27 & $38(58)$ & - & 38 & 65 \\
\hline 7 & - & $37(31)$ & 37 & - & $83(69)$ & 83 & 120 \\
\hline 8 & $3(5)$ & $14(24)$ & 17 & $8(14)$ & $33(57)$ & 41 & 58 \\
\hline Total & $65(14)$ & $86(18)$ & 151 & $140(30)$ & $183(38)$ & 323 & 474 \\
\hline
\end{tabular}


logical analysis, 44 bulls of different mating types sired the probands. For mating types 1 and 6 we found that 8 out of 17 half-sibs presented a frequency of unfit bulls outside the overall mean frequency (32\%), contrasting with mating types 5 and 8 in which just 3 out of 11 half-sibs produced unfit sons at a frequency higher than the mean (data not shown).

Table 4 shows that for the 193 Brangus-Ibagé bulls investigated genealogically the frequency of fit and unfit bulls was similar for the different mating types $\left(\chi^{2}=0.046\right.$; $\mathrm{DF}=1 ; \mathrm{p}=0.831)$. The same was observed for the carriers of the submetacentric $Y$ chromosome $\left(\chi^{2}=0.114\right.$; $D F=1$; $\mathrm{p}=0.736)$. However, in bulls originating from mating type 8 there was a higher frequency of fit bulls carrying the submetacentric Y chromosome and a lower frequency of unfit bulls carrying the acrocentric $Y$ chromosome $\left(\chi^{2}=15.327 ; \mathrm{DF}=1 ; \mathrm{p}<0.001\right)$. A half-sib appreciation is difficult in the Brangus-Ibagé breed because there were 43 bulls from mating types 4 and 8 that sired the probands.

\section{Discussion}

The crossbreeding strategies used to obtain synthetic breed bulls (Table 1) provides an ideal model to study the two types of Y chromosome morphology in the same population. Our cytogenetic and genealogical analysis shows that there was no significant direct association between the frequency of reproductively sound bulls and Y chromosome morphology for either of the racial groups. The genealogical data agrees with the cytogenetic analysis, a discrepancy being found for only $7.8 \%$ of animals from mating types 6 and 7 which had been produced by a multiple-sire mating system (Table 2), there being no other association between fertility indicators and $\mathrm{Y}$ chromosome type.

The data presented in Table 3 shows that Braford bulls suffered a culling rate $(32 \%)$ higher than that described in the literature for purebred breeds (Johnson et al., 1995; Bruner et al., 1995; Gottschall and Mattos, 1997; Ribeiro Filho et al., 1997), although similar breeding soundness culling rates have been reported for synthetic bulls (Chenoweth et al., 1996; Moraes et al., 1998; Chacon et al., 1999). In contrast to what we found for the Braford bulls, the reproductive fitness culling rate for the synthetic Brangus-Ibagé bulls was only 17\% (Table 4).

The lack of association between the Y chromosome morphology and reproductive soundness suggests that the hypothesis that chromosomal rearrangement directly effects fertility must be rejected. A possible explanation for the high reproductive fitness culling rates for Braford bulls is that this could be related to mating types, as a significant difference in the frequency of unfit bulls carrying an acrocentric Y chromosome was observed. This conclusion is supported by the fact that for the Brangus-Ibagé bulls mating types 6 and 7 were not used to produce the population of these synthetic animals. This is one possible explanation as to why the culling rate for reproductive soundness in Brangus-Ibagé bulls is within the limits of what is considered normal for purebreds.

Table 3 shows that the highest frequency of Braford bulls with semen problems occur with $1 / 4$ Nellore bulls. In mating type 6 the probands (all with acrocentric Y chromosomes) are sired by $1 / 2$ Nelore bulls, contrasting with mating type 7 in which 1/4 Nelore bulls have both types of $Y$ chromosomes because they could be sired by either of the original breeds. The bad semen quality found in some mating types could be due to the presence of an acrocentric Y chromosome because of the absence of the European genotype. The biochemical interactions that result in these negative fertility phenotypes could be due to genetic interactions that underlie complex epistasis (Johnson, 2000). This hypothesis is also supported by the familiar analysis in which only the male parents in mating types 1 and 6 presented higher frequencies of unfit sons.

Most probably a fraction of unfit bulls in the Brangus-Ibagé breed was due to reversible classical testicular degeneration caused by poor adaptation of the animals. Alternatively, in the Braford breed the increased rate of unfit bulls $(\sim 15 \%)$ could have been due to a permanent inherent condition derived from the interaction of genotypes and the different $Y$ chromosome package in both subspecies. Further evidence that this peculiar testicular degeneration is a permanent condition comes from the maintenance of the semen pictures in unfit bulls for at least six months, the different capacity that unfit Braford bulls may have to select abnormal sperm along the epididymis, and that abnormal

Table 4 - Genealogically determined frequency of the different $Y$ chromosome morphological types found in reproductively fit and unfit Brangus-Ibagé bulls.

\begin{tabular}{|c|c|c|c|c|c|c|c|}
\hline \multirow[b]{3}{*}{ Mating type } & \multicolumn{6}{|c|}{ Y chromosome morphology } & \multirow[b]{3}{*}{$\begin{array}{c}\text { Total } \\
\text { unfit + fit }\end{array}$} \\
\hline & \multicolumn{3}{|c|}{ Unfit bulls } & \multicolumn{3}{|c|}{ Fit bulls } & \\
\hline & $\begin{array}{l}\text { Acrocentric } \\
\text { number (\%) }\end{array}$ & $\begin{array}{c}\text { Submetacentric } \\
\text { number }(\%)\end{array}$ & Total unfit & $\begin{array}{l}\text { Acrocentric } \\
\text { number (\%) }\end{array}$ & $\begin{array}{c}\text { Submetacentric } \\
\text { number }(\%)\end{array}$ & Total fit & \\
\hline 4 & - & $4(22)$ & 4 & - & $14(78)$ & 14 & 18 \\
\hline 8 & $9(5)$ & $21(12)$ & 30 & $34(19)$ & $111(64)$ & 145 & 175 \\
\hline Total & $9(4)$ & $25(13)$ & 34 & $34(18)$ & $125(65)$ & 159 & 193 \\
\hline
\end{tabular}


spermatogenesis in these animals appears after the meiotic divisions and during sperm maturation (Horn et. al., 2002a, b; Horn et al., 2003).

Further research is needed to confirm the results obtained in this study because different factors can cause bulls to have low quality semen, with synthetic breeds being specifically prone to additive and heterotic gene effects which can cause disparity in distinct genotype combinations. The economic losses associated with the high reproductive soundness culling rates of bulls of some synthetic breeds means that it is well worthwhile recommending that $1 / 4$ Zebu females, or $1 / 4$ Zebu males that were not originated from European parents, should not be used to produce 3/8 Zebu bulls because if producers could sell $10-15 \%$ more fit bulls their net income would increases by about $5 \%$.

\section{Acknowledgments}

The authors are grateful to Prof. Thales Freitas from the Departamento de Genética, Universidade Federal do Rio Grande do Sul, Porto Alegre, RS, Brazil for technical assistance in preparing the karyotypes and to Drs. Carlos Galina and Carlos Souza for helpful suggestions on manuscript preparation. We also thank the Brazilian Conselho Nacional de Desenvolvimento Científico e Tecnológico $(\mathrm{CNPq})$ for a post-graduate scholarship and to the MCT-Pronex program for financial support.

\section{References}

Basrur PK and Moon YS (1967) Chromosomes of cattle, bison and their hybrid, the cattalo. Am J Vet Res 28:1319.

Britto CMC and Mello ML (1999) Morphological dimorphism in the Y chromosome of "Pé Duro" cattle in the Brazilian state of Piauí. Genet Mol Biol 22:369-373.

Bruner KA, McCraw RL, Whitacre MD and Van-Camp SD (1995) Breeding soundness examination of 1,952 yearling beef bulls in North Carolina. Theriogenology 44:129-145.

Chacón J, Pérez E, Müller E, Söderquist L and RodríguezMartinez E (1999) Breeding soundness evaluation of extensively managed bulls in Costa Rica. Theriogenology 52:221-231.

Chenoweth PJ, Chase Jr CC, Larsen RE, Thatcher MJD, Bivens JF and Wilcox CJ (1996) The assessment of sexual performance in young Bos taurus and Bos indicus beef bulls. Applied Anim Behaviour Sci 48:225-236.

Cooke HJ (1999) Y chromosome and male infertility. Rev Reprod 4:5-10.

Foresta C, Ferlin A, Garolla A, Rossato M, Barbaux S and Bortoli A (1997) Y-Chromosome deletions in idiopathic severe testiculopathies. J Clin Endocrin Metab 82:1075-1080.

Gotschall GS and Mattos RC (1997) Achados de exames andrológicos em touros de corte Bos taurus e Bos indicus. Rev Bras Reprod Anim 21:25-28.

Hale DW, Washburn LL and Eicher EM (1993) Meiotic abnormalities in hybrid mice of the C57BL/6J x Mus spretus cross suggest a cytogenetic basis for Haldane's rule of hybrid sterility. Cytogenetics Cell Gen 63:221-234.

Halnan CRE (1989) Cytogenetics of Animals. C.A.B. International, Wallingford, $519 \mathrm{pp}$.
Horn MM, Moraes JCF and Maciel MN (2002a) Variação temporal na qualidade do sêmen de touros de genótipo puro europeu e sintético derivado. Rev Bras Reprod Anim 26:324-330.

Horn MM, Moraes JCF and Edelweiss MIA (2002b) Evidência de seleção espermática diferencial no epidídimo de touros de genótipo híbrido com alteração na espermatogénese. Rev Port Ciên Vet 97:171-174.

Horn MM, Moraes JCF and Edelweiss MIA (2003) Quantificação dos estádios do ciclo espermatogênico em touros de raças sintéticas com e sem alteração na qualidade seminal. Ciência Rural 33:1111-1115.

Johnson NA (2000) Gene interactions an the origin of species. In: Wolf JB, Brodie Jr. ED and Wade MJ (eds) Epistasis and the Evolutionary Process. Oxford University Press, New York, pp 197-212.

Johnson WH, Thompson JA, Kumi-Diaka J, Wilton JW and Mandell IB (1995) The determination and correlation of reproductive parameters of performance-tested Hereford and Simmental bulls. Theriogenology 44:973-982.

Joly D, Bazin C, Zeng LW and Singh RS (1997) Genetics basis of sperm and testis length differences and epistatic effect on hybrid inviability and sperm motility between Drosophila simulans and D. sechellia. Heredity 78:354-362.

Kennedy SP, Spitzer JC, Hopkins FM, Higdon III HL and Bridges Jr WC (2002) Breeding soundness evaluations of 3648 yearling beef bulls using the 1993 Society for Theriogenology guidelines. Theriogenology 8590:1-15.

Kaku Y, Kon Y, Takagi N, Yamashita T, Hayashi M and Watanabe T (1995) Histological analysis of male hybrid sterility induced by the Hst-1 gene in mice. J Vet Med Sci 57:973-975.

Kieffer NM and Cartwright TC (1968) Sex Chromosome polymorphism in domestic cattle. J Hered 59:35-37.

Lamnissou K, Loukas M and Zouros E (1996) Incompatibilities between $\mathrm{Y}$ chromosome and autosomes are responsible for male hybrid sterility in crosses between Drosophila virilis and Drosophila texana. Heredity 76:603-609.

Moraes JCF, Horn MM and Rosado A (1998) Avaliação andrológica em touros: Qualidade dos indicadores da aptidão reprodutiva em distintos grupos raciais. Ciência Rural 28:647-652.

Pinheiro LEL, Mies Filho A, Moraes JCF and Van Hoogstraten MIMJ (1979) Avaliação andrológica de touros com polimorfismo cromossômico. Rev Bras Reprod Anim 3:23-26.

Pinheiro LEL, Moraes JCF, Mattevi MS, Erdtmann B, Salzano FM and Mies Filho A (1980) Two types of Y chromosome in a Brazilian cattle breed. Caryologia 33:25-32.

Rao BK and Rao AR (1991) Evaluation of crossbred bulls for breeding soundness. Indian J Anim Reprod 12:111-113.

Ribeiro Filho AL, Chalhoub M, Aguiar PHP, Oliveira JVL, Lopes RM, Vale Filho VR and Andrade VJ (1997) Parâmetros reprodutivos e classificação andrológica por pontos de touros Nelore PO no Estado da Bahia. Arq. Escola de Medicina Veterinária da Universidade Federal da Bahia 19:177-188.

Snook RR (1998) Sperm production and sterility in hybrids between two subspecies of Drosophila pseudoobscura. Evolution 52:266-269.

Wurster DH and Benirschke K. (1968) Chromosome studies in the superfamily Bovidae. Chromosoma 25:152-171.

Associate Editor: Pedro Franklin Barbosa 